\title{
Biodiversity of Mites Associated with Parrots and Peacocks in Giza Zoo, Egypt
}

\author{
Reham Abo-Shnaf*; Amal H. M. Romeih ${ }^{* *}$ and, Sally F. Allam ${ }^{* *}$ \\ *Plant Protection Research Institute, Agricultural Research Center, Dokki, Giza, Egypt \\ Z** Zoology and Agricultural Nematology Dept., Faculty of Agriculture, Cairo University, Egypt \\ sallyfmallam @ hotmail.com.
}

\begin{abstract}
During fall season, biodiversity of mites collected from parrots and Peacocks was recorded in Giza Zoo. Samples of dust, litter and debris from bird cages were examined. Mites were extracted using modified Tullgren funnel and mounted in Hoyer's medium on microscopic slides for examination. Seventeen mite species of 15 genera belong to ten families were identified. Theses families belong to four suborders as follow: four to Actinedida, two to Gamasida, three to Acaridida and one to Oribatida. Three species were firstly recorded; one belongs to the family Acaridae and the others to the family Cheyletidae. Types of habits of collected acari founa were noted: predacious (35.2\%), fungivourus (3.2\%), parasitic $(0.8 \%)$, phytophagous $(4 \%)$, allergen $(56.8 \%)$.
\end{abstract}

KeY WoRDs: Acari, Parrots, Peacocks, Biodiversity, Actinedida, Gamasida, Acaridida, Oribatida, Egypt.

\section{INTRODUCTION}

Acari are noted in almost every habitat available to animal life. Thus, some investigators directed their work towards mites associated with birds. Baker (1949) mentioned that, Acaropsellina docta (Berlese) occurred in large numbers in sparrow nests but less abundant in those of other birds. $\mathrm{He}$ also added that Cheletomorpha venustissima (Koch), Cheyletia flabellifera (Mich.) and Cheyletus eruditus (Schrank) were found in the nests. In Egypt, Wafe \& Soliman (1968) found the cheyletid mite Acaropsella aegyptiaca (Wafa \& Soliman) in bird nests. Twenty one mite species belonging to eight families in different bird nests in New York were recorded by Baker et al. (1976). Mohamed and Rakha (1980) recorded ten species in seven families of the suborders, Prostigmata, Mesostigmata and Astigmata inhabiting sparrow nests in Giza region. Rakha (1980) surveyed 62 newly recorded mite species associated with birds in Egypt. These represented 32 genera in 14 families of the five superfamilies: Analgoidea, Pterolichoidea, Freyanoidea, Psoroptoidea and Cytoditoidea. Of these species, 18 were considered new species. Abd-Alla (1993) collected 41 species, representing 35 genera, in 24 families belonging to the four suborders: Acaridida, Actinedida, Gamasida and Ixodida inhabiting wild birds. Eighteen of the mites were new species and two genera were new. In 1999, Morsy et al. studied the mite founa of Passer domestica niloticus and Streptopelia senegalensis aegyptiaca captured in Sharkia and Qalyobia Governorates. They collected 31 species belonging to 23 genera, 17 families of three suborders. Solarz et al., (2004) collected ten species of astigmatid mites from different macawws and cockatiels (Ara ararauna and Nymphicus hollandicus) in the Silesian Zoo, Poland. Those mites were belonging to four families: Acaridae, Glycyphagidae, Anoetidae and Pyroglyphidae.

Therefore, the present study deals with the occurrence, prevalence and species composition of predacious, phytophagus, fungivourous, parasitic and allergen mites associated with bird cages of Giza Zoo.

\section{MATERIALS AND METHODS}

This study was carried out in Giza Zoo during fall season 2007. Sixty samples of litter and debris from cages of ten kinds of birds from parrots and peacocks including [Psittacus erithacus (African Gray Parrot), Pavo cristatus (Common Peacock), Padda oryzivora (Java Finch), Cacatua galerita (Greater Sulpher-Orested Cockatoo), Nymphicus hollandicus (Pied Cockatiel), $N$. hollandicus (White Cockatiel), Ara ararauna (Red-Blue Macaww), A. ararauna (Blue \& Yellow Macaww), Amazona xanthops (Yellow Faced Amazon) and Eos bornea (Red Lory) were collected. Samples were kept in polyethylene bags, and then transferred to the laboratory for mite extraction. Mites were extracted using modified Tullgren funnels, mounted on glass slides in Hoyer's medium, for identification. Mites population densities were assessed as the number of specimens per sample of the material analyzed. Because of difficulties with standardization mite collection, the calculation of mite numbers of each taxon per sample was recommended as the best method for determining mite exposure (Platts-Mills et al., 1990). 


\section{RESULTS AND DISCUSSION}

From 60 examined samples the total extracted mite species was 125 individuals including 17 species of 15 genera, ten families and four suborders. These are: of the Suborder Actinedida, Cheletogenes ornatus Can. \& Fanz, Cheyletus fortis Oudemans, Cheyletus malaccensis Oudemans, Acaropsella kulaginii Rohdendorf, Acaropsellina sollers Rohdendorf, Neoeucheyla ornata Wafa \& Soliman and Hemicheyletia bakeri (Ehara) (Family Cheyletidae); Raphignathus arabicus Gomaa \& Hassan ${ }^{*}$ (Family Raphignathidae); Paratriophtydeus plummeri (Baker) (Family Tydeidae); Tetranychus cucurbitacearum (Sayed) (Family Tetranychidae); of the Suborder Gamasida, Macrocheles africanus Hafez, El Badry \& Nasr(1985) (Family Macrochelidae); Androlaelaps casalis (Berlease) (Family Laelapidae); of SubOrder Oribatida, Rostrozetes citri Nasr \& Hassan (Family: Haplozetidae); of the Suborder Acaridida, Dermatophagoides farinae Hughes, (Family Pyroglyphidae), Glycyphagus domesticus (De Geer), Glycyphagus ornatus Kramer (Family Glycyphagidae); Caloglyphus oudemansi (Zachvatkin) (Family Acaridae).

The Suborder Actinedida included the greatest number of genera and families, while the Acaridida was the second (Table 1). In contrast, genera and families of the Gamasida and Oribatida were few. Ten species of the actinedida were identified. They belong to four families: Cheyletidae, Raphignathidae, Tydeidae and Tetranychidae. The family Cheyletidae included the greatest number of species (seven species). This was parallel with those reported by Mohamed and Rakha (1980). Among these cheyletids, two species were considered as first record, C. fortis and A. kulagini. One species represented each of the families: Raphignathidae, Tydeidae and Tetranychidae. Only two species of Gamasida belonging to the families Macrochelidae and Laelapidae were also collected in a few numbers. One species of the family: Haplozetidae from Oribatida was found with common peacock (Pavo cristatus) in a few numbers.

Suborder Acaridida included the greatest number of individuals but not the species (Table1). It was represented by the three genera Glycyphagus, Caloglyphus and Dermatophagoides. G. domesticus of the family Glycyphagidae was collected in high numbers, while $C$. oudemansi of the family
Acaridae has been firstly recorded and found in rare numbers.

The house dust mite, D. farinae of the family Pyroglyphidae was found in relatively great numbers associated with parrots. This agrees with that mentioned by Rakha 1980 and Solarz et al. 2004 who cited that $D$. farinae was associated with parrots, canids and artiodactyls.

According to their habits, acaridid mites species presented $(56.8 \%)$ of collected mite population, followed by the predacious ones which presented $(35.2 \%)$, fungivorous (3.2\%), phytophagous $(4 \%)$ then parasitic $(0.8 \%)($ Table1). Occurrence of acaridida comprised G. domesticus (37.6\%), D. farinae $(10.4 \%), \quad$ G. ornatus $(8 \%)$ and C. oudemansi $(0.8 \%)$. Some of these mites, may considered as allergic mites. In addition, the phytophagous mite, T. cucurbitacearum (4\%) has been recently considered as allergic mite by Arlian and Platts-Mills (2001) and Arlian (2002) who mentioned that, the two-spotted spider mite Tetranychus urticae Koch and the European red mite Panomychus umli (Koch) which are common pests of plants, were recently discovered to induce IgE-mediated allergy reactions in humans. Solarz et al. (2004) stated that both allergic species of astigmatid and tetranychid constituted $45.61 \%$ of all mites found in the Silesian Zoo.

Fourty-four collected mite individuals were predators, while only one species was parasite (Table 2). These predacious mites determined (35.2\%) and considered as a big group to attack allergic and phytophagous mites to decrease its population.

Concerning birds, Pavo cristatus (Common Peacock) appeared to be the one that had numerous number of mite species among them three species belong to Acaridida (Table2). Consequently, it may be advisable to avoid direct contact with this bird followed by Padda oryzivora and Psittacus erithacus (African Gray Parrot). All the birds rest nests had only the predacious mites, while the phytophagous one was associated with Eos bornea (Red Lory) and Nymphicus hollandicus.

Only four fungivorous were surveyed. These mites may feed on harmful and pathogenic fungi inhabiting birds nests and representing $3.2 \%$ of the total mites.

\footnotetext{
Cited by Zaher 1986.
} 
Table (1): Species list, occurrence, frequency and mean number of mites per sample, and per total samples from the examined places in the Giza Zoo.

\begin{tabular}{|c|c|c|c|c|c|}
\hline \multirow[b]{2}{*}{ Mite group } & \multirow[b]{2}{*}{ Mite taxa } & \multicolumn{4}{|c|}{ Frequency } \\
\hline & & $\begin{array}{c}\text { No. of } \\
\text { samples }\end{array}$ & $\begin{array}{l}\text { Total number of } \\
\text { mites collected }\end{array}$ & $\begin{array}{c}\% \text { of the total } \\
\text { count }\end{array}$ & $\begin{array}{l}\text { Mean no. of mites } \\
\text { per sample }\end{array}$ \\
\hline \multirow[t]{4}{*}{ Allergic } & Dermatophagoides farinae & 06 & 13 & 10.4 & 2.17 \\
\hline & Glycyphagus domesticus & 12 & 47 & 37.6 & 4.70 \\
\hline & G. ornatus & 03 & 10 & 08.0 & 3.33 \\
\hline & Caloglyphus oudemansi & 01 & 1 & 00.8 & 1.00 \\
\hline Total & & & 71 & 56.8 & \\
\hline \multirow{2}{*}{ Fungivorous } & Paratriophtydeus plummeri & 01 & 01 & 00.8 & 01.0 \\
\hline & Rostrozetes citri & 02 & 03 & 02.4 & 01.5 \\
\hline Total & & & 04 & 03.2 & \\
\hline \multirow{9}{*}{ Predacious } & Cheletogenes ornates & 01 & 01 & 00.8 & 01.0 \\
\hline & Cheyletus fortis & 04 & 04 & 03.2 & 01.0 \\
\hline & C. malaccensis & 02 & 02 & 01.6 & 01.0 \\
\hline & Acaropsella kulagini & 07 & 14 & 11.2 & 02.0 \\
\hline & Acaropsellina sollers & 12 & 19 & 15.2 & 1.58 \\
\hline & Neoeucheyla ornate & 01 & 01 & 00.8 & 01.0 \\
\hline & Hemicheyletia bakeri & 01 & 01 & 00.8 & 01.0 \\
\hline & Raphignathus arabicus & 01 & 01 & 00.8 & 01.0 \\
\hline & Macrocheles africanus & 01 & 01 & 00.8 & 01.0 \\
\hline Total & & & 44 & 35.2 & \\
\hline Parasitic & Androlaelaps casalis & 01 & 01 & 00.8 & 01.0 \\
\hline Phytophagous & T. cucurbitacearum & 04 & 05 & 04.0 & 1.25 \\
\hline
\end{tabular}

Table (2): Incidence of different mite species in bird cages at Giza Zoo, Egypt.

\begin{tabular}{|c|c|}
\hline Bird species & Mite species \\
\hline $\begin{array}{l}\text { Psittacus erithacus (African Gray } \\
\text { Parrot) }\end{array}$ & $\begin{array}{l}\text { Dermatophagoides farinae Hughes, Cheyletus malaccensis Oudemans, } \\
\text { Acaropsellina sollers Rohdendorf, Neoeucheyla ornata Wafa \& Soliman }\end{array}$ \\
\hline Pavo cristatus (Common Peacock) & $\begin{array}{l}\text { Dermatophagoides farinae Hughes, Glycyphagus domesticus (De Geer), } \\
\text { G. ornatus Kramer, Paratriophtydeus plummeri (Baker), } \\
\text { Cheyletus fortis Oudemans, Caloglyphus oudemansi (Zachvatkin), } \\
\text { Acaropsellina sollers Rohdendorf, Raphignathus arabicus Gomaa \& Hassan, } \\
\text { Macrocheles africanus Hafez, El Badry \& Nasr(1985), } \\
\text { Androlaelaps casalis (Berlease), Rostrozetes citri Nasr \& Hassan, } \\
\text { Dermatophagoides farinae Hughes }\end{array}$ \\
\hline Padda oryzivora (Java Finch) & $\begin{array}{l}\text { Dermatophagoides farinae Hughes, Cheyletus fortis Oudemans, } \\
\text { Acaropsellina sollers Rohdendorf }\end{array}$ \\
\hline $\begin{array}{l}\text { Cacatua galerita (Greater Sulpher- } \\
\text { Orested Cockatoo) }\end{array}$ & Cheletogenes ornates Can. \& Fanz. \\
\hline $\begin{array}{l}\text { Nymphicus hollandicus (Pied } \\
\text { Cockatiel) }\end{array}$ & $\begin{array}{l}\text { Acaropsella kulagini Rohdendorf, Acaropsellina sollers Rohdendorf, } \\
\text { Tetranychus cucurbitacearum (Sayed) }\end{array}$ \\
\hline N. hollandicus (White Cockatiel) & Acaropsella kulagini Rohdendorf, Acaropsellina sollers Rohdendorf \\
\hline Ara ararauna (Red-Blue Macaww) & Acaropsella kulagini Rohdendorf \\
\hline $\begin{array}{l}\text { A. ararauna (Blue \& Yellow } \\
\text { Macaww) }\end{array}$ & Acaropsella kulagini Rohdendorf \\
\hline $\begin{array}{l}\text { Amazona xanthops (Yellow Faced } \\
\text { Amazon) }\end{array}$ & $\begin{array}{l}\text { Acaropsellina sollers Rohdendorf, } \\
\text { Hemicheyletia bakeri ( Ehara) }\end{array}$ \\
\hline Eos bornea (Red Lory) & Tetranychus cucurbitacearum (Sayed) \\
\hline
\end{tabular}




\section{REFERENCES}

Abd-Alla, A. A. 1993. Studies on mites inhabiting wild birds. M. Sc. Thesis, Fac. Agric., Al-Azhar Univ., 209 pp.

Arlian, L. G. 2002. Arthropod allergens and human health. Ann. Rev. Entomol., 47: 395-433.

Arlian, L. G. and Platts-Mills, T. A. E. 2001. The biology of dust mites and the remediation of mite allergens in allergic disease. J. Allergy Clin. Immunol., 107: 406-413.

Baker, E. W. 1949. A review of the mites of family Cheyletidae in the United States National Museum. Proc. U.S. Nat. Mus., 99 (3238): 267320.

Baker, E. W.; Delfinado, M. D. and Abbotiello, M. J. 1976. Terrestrial mites of New York II. Mites in bird nests (Acarina). J. New York Ent. Soc., 84 (1): 48-66.

Hafez, S. M., EL-Badry, E.A. and Nasr, A. K. 1985. Four new macrochelid mites from Egypt. Bull. Fac. Agric., Ain Shams University,

Mohamed, M. I. and Rakha, M. A. 1980. Survey of mites occurring in bird nests at Giza region, A. R. E. Res. Bull. Zagazig Univ., 205: 1- 5.
Morsy, T. A.; Mazyad, S. A. M. and Younis, M. S. 1999. Feather and nest mites of two common resident birds in two ecologically different Egyptian Governorates. J. Egypt. Society of Parasitology. 29 (2): 417-430.

Platts-Mills, T. A. E.; Thomas, W. R.; Aalberse, R. C.; Vervloet, D. and Chapman, M. D. 1990. Dust mite allergens and asthma: Report of a second international workshop. J. Allergy Clin. Immunol., 89: 1046-1060.

Rakha, M. A. 1980. Taxonomical and biological studies on some astigmatid mites of birds. Ph.D. Thesis, Fac. Agric., Cairo Univ., 413 pp.

Solarz, K.; Szilman, P. and Szilman, E. 2004. Occupational exposure to allergenic mites in a polish Zoo. Ann. Agric. Environ. Med., 11:27-33.

Wafa, A. K. and Soliman, Z. R. 1968. Five genera, of family Cheyletidae (Acarina) in the U.A.R. with a description of four new species. Acarologia, 10 (2): 220-229.

Zaher, M. A.1986. Survey and ecological studies on phytophagous, predaceous mites in Egypt. II predaceous and nonphytophagous mMites. PL. 480 Programme Project No. fg-eg 139, 567 pp. 